\title{
MERETAS AKTUALITAS ISLAMIC SOCIAL REPORT: SEBAGAI CORPORATE SOCIAL RESPONSIBILITIES FRAMING BERBASIS SYARIAH (DALAM PENDEKATAN FILOSOFIS)
}

\author{
Bayu Tri Cahya \\ Dosen Program Studi Ekonomi Syariah STAIN Kudus \\ email:cahyab380@gmail.com \\ Umi Hanifah \\ Magister Akuntansi Univ. Muh. Surakarta (UMS) \\ E-mail: hanifahumi80@gmail.com
}

\begin{abstract}
This article analysed the concept of islamic social development report as a frame of sharia-based corporate social responsibilities. The study was conducted by library research based on previous studies and related literature. The results indicated that the concept of social islamic report was based on the philosophy of good governance and corporate social performance reporting standard that takes into account the aspects of material, moral, and spiritual in reporting. In particular, this index is an extension of social performance reporting standards which include society's expectations not only about the role of corporations in the economy, but also the company's role in the spiritual perspective. Besides the index also places emphasis on social justice related to the environment, the rights of minorities, and employees. Finally, syariah framework is part of a corporate strategy aimed at the sustainability of the company, providing benefits to the community and participate in the social interest.
\end{abstract}


Keywords: islamic social report, syariah framework, philosophy

\section{A. Pendahuluan}

Satu-satunya tanggung jawab sosial entitas atau korporasi adalah meningkatkan keuntungan bagi pemegang saham, mungkin benar secara konteks pada tahun 1960an atau 1970an (Friedman, 1970). Hal tersebut didasari oleh pemikiran filosofi dualism yang cenderung cara berfikirnya konvensional, bahwa tugas korporasi adalah mencari keuntungan. Setelah mendapat keuntungan, korporasi baru memperhatikan persoalan sosial. Persoalan dari pemikiran filosofis ini adalah sifat tamak (profit maximization) dari korporasi sulit dikontrol oleh hukum. Kapan korporasi akan menentukan bahwa keuntunganya telah cukup, dan saatnya untuk memperhatikan persoalan sosial, adalah tidak dapat diperkirakan (Clark, 1986:675). Sebenarnya secara teoritik, para pendiri perusahaan membuat kontrak untuk bekerjasama mendirikan korporasi dengan maksud dan tujuan individualistik (privately). Artinya mereka hanya melimpahkan amanat kepada direksi sesuai dengan maksud dan tujuan pendirian korporasi (Fall, 1993:1683), dimana pada umumnya mereka hanya befokus pada profit oriented.

Secara faktual, kondisi dan nilai nilai masyarakat telah berubah. Masyarakat dunia yang sebagian ikut merasakan adanya ketimpangan sosial dan kemalangan yang harus dididerita oleh sebagian saudara yang lainnya, akan mempunyai ekspektasi yang berbeda terhadap korporasi (Faajar, 2013:100). Bisnis bukan lagi sebagai entitas yang hanya mementingkan dirinya sendiri saja sehingga tereliminasi dari lingkungan masyarakat di tempat mereka bekerja, melainkan sebuah entitas usaha yang wajib melakukan adaptasi kultural dengan lingkungan (Daniri, 2006). Perubahan lingkungan yang sangat dinamis, baik 
dipicu oleh kekuatan eksternal maupun kekuatan internal telah memaksa para pelaku bisnis untuk tidak saja harus selalu meningkatkan laba dan kinerja, tetapi juga mesti peduli terhadap problem sosial. Semakin besarnya kekuasaan terhadap kualitas kehidupan manusia, baik individu, masyarakat, maupun kehidupan seluruh jagat ini. Fenomena inilah yang menyulut wacana corporate social responsibility (CSR) yang menekankan bahwa tanggung jawab perusahaan bukan lagi sekadar aktifitas ekonomi (menciptakan profit demi kelangsung bisnis), melainkan juga termasuk jawab sosial termasuk lingkungan (Kartini, 2013:i). Dalam konteks ini CSR justru menjadi norma yang layak untuk dilakukan karena mendukung untuk increasing profit (Turnbull, 2005).

Sesungguhnya Dalam menerapkan social responsibilities, persoalan moralitas bisnis justru harus diredefinisikan kembali dengan lebih jelas. Jika para pengelola atau direksi perusahaan melakukan social responsibilities, dengan memberikan sumbangan pada masyarakat atas dama perusahaan, sesungguhnya dia telah melakukan tindakan pribadi (Coelho dan James, tt:6).

CSR merupakan wacana yang makin umum dalam dunia bisnis di Indonesia, dimana fenomena ini dipicu oleh semakin mengglobalnya tren mengenai praktek CSR dalam bisnis (Fitria dan Hartanti, 2010:1). Sebagai salah pendekatan sukarela yang berada pada tingkat beyond compliance, penerapan CSR saat ini berkembang pesat termasuk di Indonesia sebagai respon dunia usaha yang melihat aspek lingkungan dan sosial sebagai peluang untuk meningkatkan daya saing serta sebagai bagian dari pengelolaan resiko, menuju sustanaibility dari kegiatan usahannya (Kartini, 2013:ii). Substansi keberadaan prinsip tanggung jawab sosial perusahaan (CSR) adalah dalam rangka memperkuat perusahaan untuk beradaptasi dengan lingkungannya. Komunitas dan stakeholder yang terkait dengannya baik lokal, nasional maupun global. 
Secara singkat CSR mengandung makna bahwa perusahaan memiliki tugas moral jujur, mematuhi hukum, menjunjung integritas dan tidak korupsi. CSR menekankan bahwa perusahaan mesti mengembangkan praktik bisnis yang etis dan sustainable, secara ekonomi, sosial dan lingkungan. Tidak mengherangkan kalau kemudian dianggap CSR dianggap sebagai jawaban terhadap praktik bisnis yang mencari untung sebesar besar nya. Bahkan sementara kalangan menganggap bahwa CSR dinaggap sebagai beban yang menganggu konsentrasi perusahaan untuk memaksimalkan nilai bagi stakeholder (Kartini, 2013:ii). Perkembangan praktik dan pengungkapan CSR di Indonesia juga mendapat dukungan dari pemerintah. Halitu, terlihat dengan diterbitkannya Undang-Undang No. 40 Tahun 2007 Pasal 74 oleh pemerintah terkait dengan kewajiban perusahaan yang menjalankan usaha dibidang atau berkaitan dengan sumber daya alam untuk melaksanakan tanggungjawab sosial dan lingkungan. Konsep CSR kini tidak hanya berkembang di ekonomi konvensional, tetapi juga berkembang dalam ekonomi Islam.

Berkembangnya social report dalam ekonomi Islam juga turut meningkatkan perhatian masyarakat terhadap lembaga atau institusi syariah. Hal tersebut dikarenakan adanya kebutuhan masyarakat untuk mengenal secara lebih dalam terhadap lembaga atau institusi syariah, semakin besar dari waktu ke waktu. Pasar modal sebagai lembaga dan profesi yang berkaitan dengan efek dalam hal ini adalah pasar modal syariah berperan penting dalam meningkatkan pangsa pasar efek-efek syariah pada perusahaan-perusahaan ingin berpartisipasi dalam pasar modal syariah di Indonesia. Perkembangan pasar modal syariah yang begitu cepat membuat perusahaan diekspektasikan untuk menyajikan suatu dimensi religi dalam pengungkapan laporan tahunan yang bertujuan untuk memberi manfaat bagi pemangku kepentingan 
muslim. Oleh karena itu, dibutuhkan acuan (guideline) untuk mengukur sejauh mana perusahaan-perusahaan tersebut membuat laporan tanggung jawab sosial yang turut menyajikan aspek-aspek religi dalam laporan tahunan dengan menyajikan pemenuhan kewajiban perusahaan yang sesuai dengan syariah (Othman, 2010:138).

Sejauh ini pengukuran CSR disclosure pada lembaga syariah kebanyakan masih mengacu kepada Global Reporting Initiative Index (Indeks GRI) (Haniffa, 2002:130). Padahal, terkait dengan adanya kebutuhan mengenai pengungkapan aktivitas sosial di entitas binis syariah, saat ini marak diperbincangkan mengenai Islamic Social Reporting Index (ISR). Maliah et. al (2003:27) menekankan bahwa ada dua hal yang harus diungkapkan dalam perspektif Islam, yaitu: pengungkapan penuh (full disclosure) dan akuntabilitas sosial (social accountability. Konsep akuntabilitas sosial terkait dengan prinsip pengungkapan penuh dengan tujuan untuk memenuhi kebutuhan publik akan suatu informasi. Dalam konteks Islam, masyarakat mempunyai hak untuk mengetahui berbagai informasi mengenai aktivitas organisasi. Hal ini dilakukan untuk melihat apakah perusahaan tetap melakukan kegiatannya sesuai syariah dan mencapai tujuan yang telah ditetapkan. Salah satu cara untuk memberikan pengungkapan penuh dalam konteks Islam adalah dengan ISR (Othman et al, 2009:5).

Indeks ISR merupakan tolok ukur pelak-sanakaan aktivitas sosial perbankan syariah yang berisi kompilasi item-item standar CSR Conduct and Disclousure for Islamic Financial Institusions yang ditetapkan oleh AAOIFI (Accounting and Auditing Organization for Islamic Financial Institutions) padaGovernance Standard for Islamic Social Institusions No. 7 yang kemudian dikembangkanlebih lanjut oleh para peneliti mengenai item-item CSR yang 
seharusnya diungkapkan oleh suatu entitas Islam (Othman et al, 2009:5).

ISR ini pertama kali dikemukakan oleh Haniffa (2002: 132), kemudian dikembangkan ekstensif oleh Othman et al (2009) secara spesifik di Malaysia. Menurut Haniffa (2002) terdapat keterbatasan dalam laporan sosial konvensional sehingga ia mengemukakan kerangka konseptual Islamic Social Reporting berdasarkan ketentuan syariah Islam tidak hanya untuk membantu para pengambil keputusan Muslim tetapi juga untuk membantu perusahaan, terutama perusahaan yang sesuai ketentuan syariah, dalam rangka pemenuhan kewajiban terhadap Allah SWT dan masyarakat sekitarnya.Oleh karena itu pada kajian ini berusaha untuk mengungkap bertujuan untuk memaparkan bagaimana aktualitas islamic social report digunakan sebagai dasar dan arah pengembangan tanggung jawab sosial khususnya untuk entitas bisnis yang berbasis syariah. Pendekatan yang digunakan adalah pendekatan output dengan melakukan penelusuran terhadap output dari sebuah proses filsafat, yaitu wujud fisik dari terciptanya sebuah konsep islamic social report sejak pertama kali hingga perkembangan terkini, dan diakhiri dengan uraian tentang conseptual shariah framework berserta deskripsi logis yang komprehensif mengenai arah pengembangan ke depan dengan basis tiga pilar filsafat ilmu, yaitu ontologi, epistemologi, dan aksiologi.

\section{B. Pembahasan}

\section{Konsep Tanggung Jawab Korporasi Dalam Islam}

Konsep tanggung jawab korporasi tidak hanya berkembang pada ekonomi konvensional, tetapi juga merambah ekonomi Islam. Dalam ekonomi Islam erat kaitannya dengan perusahaan-perusahaan yang menjalankan kegiatan bisnis sesuai dengan konsep syariah yang diharapkan perusahaan tersebut dapat melakukan tanggung jawab sosial perusahaan secara Islami. Nilai-nilai 
Islam yang dibawa oleh Nabi Muhammad SAW dapat digunakan sebagai landasan tanggung jawab sosial perusahaan sama seperti halnya pada perusahaan konvensional (Siwar et., al, 2009:292). Konsep ini dalam Islam lebih menekankan bentuk ketaqwaan umat manusia kepada Allah SWT dalam dimensi perusahaan. Siwar dan Hossain (2009: 292) dalam penelitiannya, mereka menyimpulkan bahwa nilai-nilai Islam memiliki hubungan yang relevan dan memiliki kontribusi terhadap konsep CSR yang telah berkembang hingga saat ini.

Tanggung jawab sosial dari sudut pandang Islam berasal dari prinsip yang terdapat dalam Al-Quran. Farook menyimpulkan tiga prinsip yang mendasari tanggung jawab sosial di dalam Islam, yaitu perwakilan (vicegerency), tanggung jawab terhadap Allah (divine accountability), serta menyuruh kepada yang ma'ruf dan mencegah kemungkaran (enjoining good and forbidding evil) (Farook, 2009:70).

Prinsip perwakilan menjelaskan bahwa manusia adalah perwakilan dari Allah di bumi. Allah berfirman dalam Al-Quran surat Al-Baqarah ayat 30: "Sesungguhnya Aku hendak menjadikan seorang khalifah di muka bumi", dan dalam surat Al-An'am ayat 165: "Dan Dialah yang menjadikan kamu penguasa-penguasa di bumi". Dengan demikian, manusia dipercaya untuk mengelola dan menjaga segala kepunyaan Allah di muka bumi.

Prinsip kedua yaitu tanggung jawab kepada Allah. Prinsip ini menggambarkan bahwa setiap manusia akan dimintai pertanggungjawaban pada hari pembalasan atas apa yang dilakukannya di dunia. Tanggung jawab kepada Allah merupakan dasar bagi semua tindakan dari umat muslim, begitupun dengan organisasi Islam. Beberapa ayat dalam Al-Quran menerangkan prinsip tersebut, dua diantaranya yaitu surat Al-Zalzalah ayat 7: "Barangsiapa yang mengerjakan kebaikan seberat dzarrahpun, niscaya dia akan 
melihat (balasan)nya" dan surat An-Nisa ayat 86: "Sesungguhnya Allah memperhitungkan segala sesuatu".

Prinsip ketiga yang merangkum dua prinsip sebelumnya adalah menyuruh kepada yang ma'ruf dan mencegah kemungkaran. Prinsip ini terdapat dalam surat At-Taubah ayat 71: "Dan orang-orang yang beriman, lelaki dan perempuan, sebahagian mereka (adalah) menjadi penolong bagi sebahagian yang lain. Mereka menyuruh (mengerjakan) yang ma'ruf, mencegah dari yang mungkar". Tanggung jawab ini melingkupi semua aspek dalam kehidupan umat muslim.

\section{Islamic Social Report}

Sejalan dengan makin meningkatnya pelaksanaan Corporate Social Reporting (CSR) dalam dunia bisnis, maka makin meningkat pula keinginan untuk membuat pelaporan sosial atau yang sering disebut dengan social reporting. Banyak pendapat yang menjelaskan mengenai pengungkapan social reporting. Social Reporting merupakan perluasan dari sistem pelaporan keuangan yang merefleksikan perkiraan yang baru dan yang lebih luas dari masyarakat sehubungan dengan peran komunitas bisnis dalam perekonomian (Haniffa, 2002:133). Kaitannya dengan Islam, Islam telah menjelaskan cukup jelas mengenai hak dan kewajiban bagi individu maupun bagi organisasi berdasarkan Al-Quran dan Hadist. Hal tersebut dikarenakan Islam adalah agama yang secara lengkap mengatur seluruh aspek kehidupan manusia di muka bumi. Siwar dan Hossain (2009:293) menyatakan bahwa landasan dasar dari agama Islam adalah aqidah (belief and faith), ibadah (worship), dan akhlaq (morality and ethics). Utamanya dalam ekonomi adalah akuntabilitas, salah satu bentuk akuntabilitas dalam perspektif ekonomi Islam adalah pelaporan tanggung jawab sosial perusahaan yang sesuai dengan prinsip syariah. Dalam ekonomi konvensional, pelaporan tanggung jawab sosial dikenal dengan perpanjangan dari sistem pelaporan keuangan 
yang merefleksikan ekspektasi sosial yang lebih luas sehubungan dengan peran masyarakat dalam ekonomi atau kegiatan bisnis perusahaan.

Saat ini tuntutan publik agar perusahaan melakukan dan mengungkapkan CSR cukup tinggi, ini terjadi karena kesadaran masyarakat mengenai pentingnya CSR. Seperti dikemukakan oleh Fitria dan Hartanti (2010) bahwa tanggung jawab sosial (CSR) merupakan wacana yang makin umum dalam dunia bisnis di Indonesia, dimana fenomena ini dipicu oleh semakin mengglobalnya tren mengenai praktek CSR dalam bisnis.

\section{ISR Sebagai The ShariaFramework}

Sebelum membahas Islamic Social Reporting (selanjutnya ISR), akan dibahas tentang kerangka syariah (the sharia framework) terlebih dahulu. Kerangka syariah pertama kali Ross Haniffa pada tahun 2002 dalam tulisannya yang berjudul "Social Reporting Disclosure : An Islamic Perspective". ISR lebih lanjut dikembangkan secara lebih ekstensif oleh Rohana Othman, Azlan Md Thani, dan Erlane K Ghanipa data hun 2009 di Malaysia dan saat ini ISR masih terus dikembangkan oleh peneliti-peneliti selanjutnya. Menurut Haniffa (2002) terdapat banyak keterbatasan dalam pelaporan social konvensional, sehingga ia mengemukakan kerangka konseptual ISR yang berdasarkan ketentuan syariah. ISR tidak hanya membantu pengambilan keputusan bagi pihak muslim melainkan juga untuk membantu perusahaan dalam melakukan pemenuhan kewajiban terhadap Allah dan masyarakat menjadi landasan dasar atas terbentuknya ISR yang komprehensif. Kerangka syariah ini akan menghasilkan aspek-aspek material, moral, dan spiritual dalam pelaporan ISR perusahaan. Dalam kerangka syariah, tauhid merupakan pondasi dari ajaran Islam. Secara bahasa, tauhid berasal dari kata Ahad, yang artinya satu, tunggal, esa. Sedang secara istilah, tauhid memiliki makna 
yakin bahwaAllah SWT adalah esa dan tidak ada sekutu bagi-Nya dalam rububiyah (ketuhanan), uluhiyah (Ibadah), asma "(nama-nama),dan sifat-sifat-Nya. Dengan tauhid menunjukan bahwa alam semesta ini satu dan bahwa kesatuan seluruh isi dan tatanannya ekonomi, politik, sosial, maupun lingkungan di alam semesta ini di ikat oleh sebuah inti. Inti itu adalah Tauhid (QS.Thaha:53-54). Wujud dari tauhid adalah syahadat. Yaitu pengakuan akan keesaan Allah SWT yang diyakini dalam hati, dibenarkan dengan lisannya, dan dibuktikan dengan amal perbuatan nyata. Syahadat menja disalah satu rukun Islam dan merupakan syarat utama seseorang masuk agama Islam. Orang yang mengucapkan syahadat akan menerima konsekwensi dari tauhid berupa kewajiban untuk tunduk terhadap segala hukum Allah SWT yang bersumber dari AlQuran, hadist, fikih, dan sumber lainya seperti Qias, Ijtihad, dan Ijma. Tujuan dari hukum syariah ini adalah untuk menegakkan keadilan sosial dan mencapai kebahagian di dunia dan di akhirat (al falah) )(Haniffa, 2002:134) Kemudian hukum syariah ini akan menjadi dasar terbentuknya konsepetika dalam Islam. Secara umum, etika dalam Islam terdiri dari sepuluh etika yang mengatur hubungan manusia dengan Allah SWT, manusia dengan manusia ,dan manusia dengan alam semesta. Kesepuluh konsepetika tersebut adalah iman (faith), taqwa (piety), amanah (trust), ibadah (workship), khilafah (vicegerent), ummah (community), keyakinan akan datangnya hari kiamat (akhirah day of reckoning), adl (justice) dan zulm (tyrnny), halal (allowable) dan haram (forbidden), sertai"tidal (moderation) dan israf (extravagance). Etika ini akan menjadi landasan manusia dalam melakukan aktivitas politik, ekonomi, dan sosial. ISR berada pada lingkup aktivitas ekonomi, khususnya aspek akuntansi. Dengan demikian, ISR merupakan bagian dari kerangka syariah. 


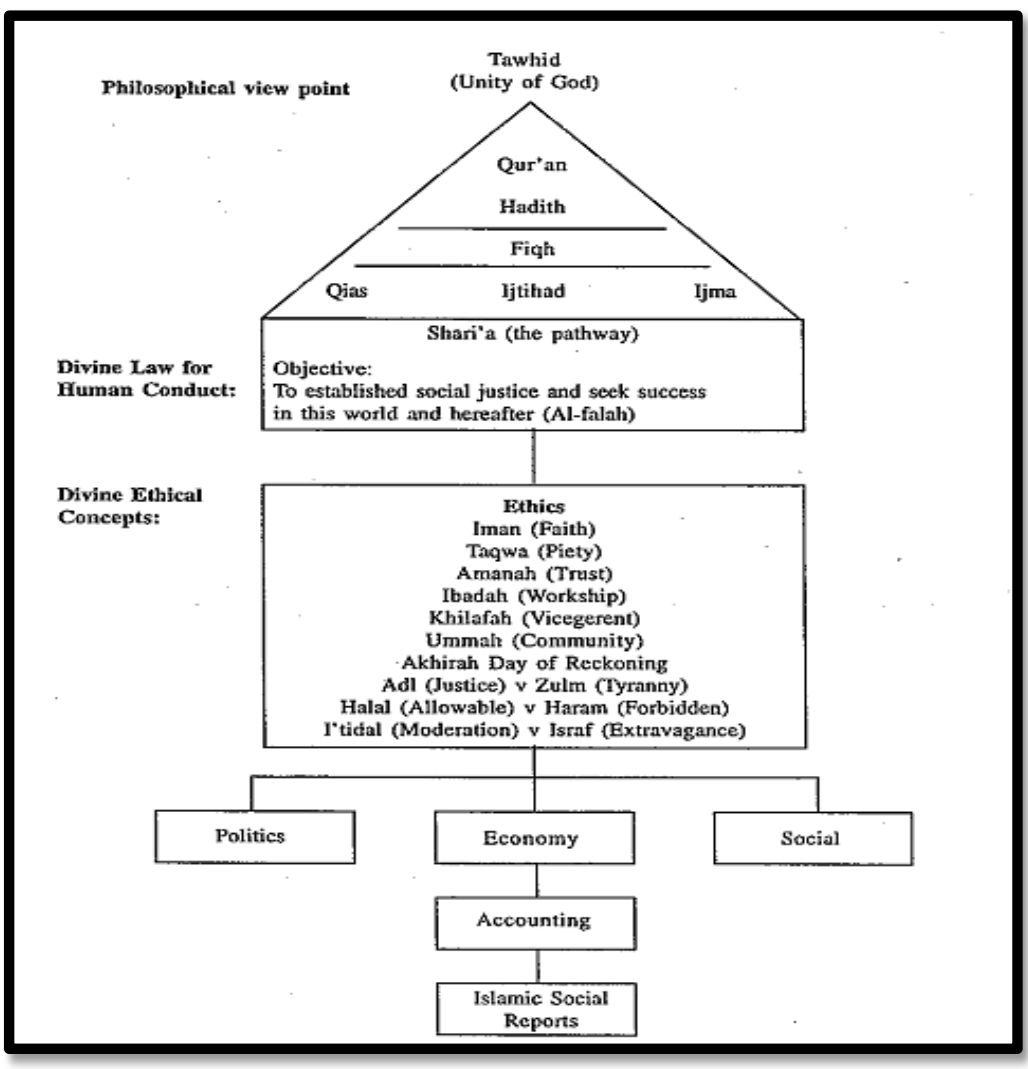

ISR adalah standar pelaporan kinerja sosial perusahaan-perusahaan yang berbasis syariah. Indeks ini lahir dikembangkan dengan dasar dari standar pelaporan berdasarkan AAOIFI yang kemudian dikembangkan oleh masing- masing peneliti berikutnya. Secara khusus indeks ini adalah perluasan dar istandar pelaporan kinerja sosial yang meliputi harapan masyarakat tidak hanya mengenai peran perusahaan dalam perekonomian, tetapi juga peran perusahaan dalam perspekti fspiritual. Selain itu indeks ini juga menekan pada keadilan sosial terkait mengenai lingkungan, hak minoritas, dan karyawan (Fitri et al, 2010:6). 


\section{BentukAkuntabilitas danTransparansi DalamISR TujuanISR}

- Sebagai bentuk akuntabilitas kepadaAllah SWTdan masyarakat

- Meningkatkan transparansi kegiatan bisnis dengan menyajikan informasi yang relevan dengan memperhatikan kebutuhan spiritual investor muslim atau kepatuhan syariah dalam pengambilan keputusan

\begin{tabular}{|c|c|}
\hline & \\
\hline $\begin{array}{l}\text { 1. Menyediakan prduk yang } \\
\text { halal dan bai } \\
\text { 2. Memenuhi hak-hak } \\
\text { Allah dan masyarakat } \\
\text { 3. Mengejar keuntungan } \\
\text { yang wajar sesuai dengan } \\
\text { prinsip Islam } \\
\text { 4. Mencapai tujuan usaha } \\
\text { bisnis } \\
\text { 5. Menjadi karyawan } \\
\text { dan masyarakat } \\
\text { 6. Memastikan kegiatan } \\
\text { usaha yang berkelanjutan } \\
\text { secara ekologis } \\
\text { 7. Menjadikan pekerjaan } \\
\text { sebagai bentuk ibadah }\end{array}$ & $\begin{array}{l}\text { 1. } \begin{array}{l}\text { Memberikan informasi } \\
\text { mengenai semua kegiatan }\end{array} \\
\text { halal dan haram dilakukan } \\
\text { 2. Memberikan informasi yang } \\
\text { relevan mengenai } \\
\text { pembiayaan dan kebijakan } \\
\text { investasi r } \\
\text { 3. Memberikan informasi yang } \\
\text { relevan mengenai kebijakan } \\
\text { karyawan an } \\
\text { 4. Memberikan informasi yang } \\
\text { relevan mengenai hubungan } \\
\text { dengan masyarakat } \\
\text { 5. Memberikan informasi yang } \\
\text { relevan mengenai } \\
\text { penggunaan sumber daya } \\
\text { dan perlindungan } \\
\text { lingkungan }\end{array}$ \\
\hline
\end{tabular}

Sumber: diolah dari Haniffa (2002), 2015

\section{Substansi Muatan ISR}

Untuk mengukur sejauh mana ISR, metode analisis isi digunakan untuk mengukur informasi Islam diungkapkan dalam laporan tahunan perusahaan yang terdaftar yang berbasis syariah. Analisis isi/muatan yang dipilih sebagai metode yang paling umum digunakan untuk memeriksa bahan tertulis yang terdapat dalam 
laporan tahunan (Othman et al, 2010:140).Indeks ISR adalah item-item pengungkapan yang digunakan sebagai indikator dalam pelaporan kinerja sosial institusi bisnis syariah. Haniffa (2002:140) membuat limatema pengungkapan Indeks ISR, yaitu Tema Pendanaan dan Investasi, Tema Produk dan Jasa, Tema Karyawa, Tema Masyarakat, dan Tema Lingkungan Hidup. Kemudian dikembangkan oleh Othman etal (2009:137) dengan menambahkan satu tema pengungkapan yaitu tema Tata Kelola Perusahaan. Setiap tema pengungkapan memiliki sub-tema sebagai indikator pengungkapan tematersebut.

\section{a. Pendanaan danInvestasi (FinanceE Investment)}

Informasi yang akan diungkapkan adalah apakah sumber pembiayaan dan investasi yang bebas bunga (riba) dan spekulatif (gharar) karena ini adalah sangat dilarang (haram) dalam Islam (Othman, 2010:137) sebagaimana disebutkan dalamAl-Qur'an:

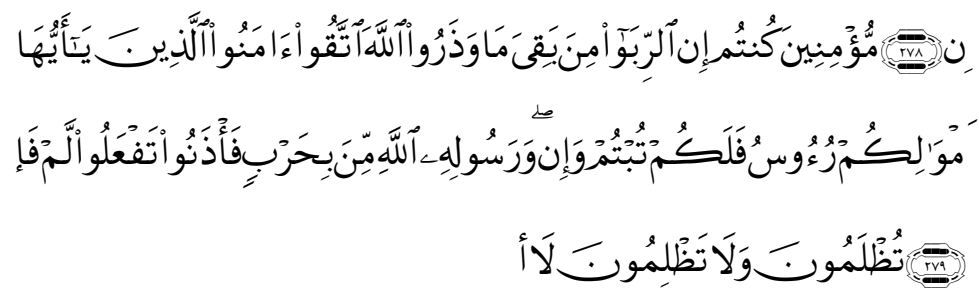

Hai orang-orang yang beriman, bertakwalah kepada Allah dan tinggalkan sisa Riba (yang belum dipungut) jika kamu orangorang yang beriman. 279. Maka jika kamu tidak mengerjakan (meninggalkan sisa riba), Maka ketahuilah, bahwa Allah dan Rasul-Nya akan memerangimu. dan jika kamu bertaubat (dari pengambilan riba), Maka bagimu pokok hartamu; kamu tidak Menganiaya dan tidak (pula) dianiaya. (QS. Al Baqoroh ayat $278-279$ )

\section{b. Produk danJasa(Products and Services)}

Konsep ini merupakan tanggung jawab perusahaan untuk mengungkapkan semua produk atau jasa yang jatuh ke dalam kategoriharam (dilarang) seperti 
minuman keras, babi, transaksi senjata, perjudian dan hiburan. Muslim benar-benar peduli dengan status halal dari produk/jasa (Haniffa, 2002: 140). Ini didukung oleh hadis berikut: Sesungguhnya Allah dan Rasul-Nya telah melarang penjualan anggur, bangkai, babi dan berhala (HR Muslim).

\section{c. Karyawan(Employees)}

Masyarakat Islam perlu tahu jika perusahaan ditangani secara adil dengan karyawan melalui informasi seperti upah, sifat pekerjaan, jam kerja per hari, cuti tahunan, kesehatan dan kesejahteraan, kebijakan mengenai hal-hal keagamaan seperti waktu shalat dan tempat, pendidikan dan pelatihan dukungan kepada karyawan, kesempatan yang sama dan lingkungan kerja (Othman et al, 2010:138). Pengusaha diharapkan untuk bermurah hati kepada karyawan mereka seperti yang dinyatakan dalam hadis: Dengan mengambil pekerjaan dari seseorang tanpa membayar dia upah yang sah adalah setara dengan menekan orang bebas ke dalam perbudakan dan untuk menghasilkan barang dari pekerjaannya, karena, ketika ia telah menuai manfaat tanpa menawarkan kompensasi, ia telah membeli buruh dan berlaku telah menganggapnya sebagai budak yang ia telah membeli (Bukhari).

\section{d. Masyarakat (Community Involvement)}

Kebutuhan umat atau masyarakat luas dapat dicapai melalui saddaqa (amal), wakaf (trust) (Haniffa, 2002:140) dan Qardhassan (pinjaman tanpa profir). Perusahaan-perusahaan harus mengungkapkan perannya dalam meningkatkan pembangunan ekonomi dan mengatasi masalah sosial misalnya; perumahan, melek huruf, beasiswa, dll dari masyarakat di mana mereka beroperasi (Casson Iet al, 2006:270). Seperti yang tercantum dalam Alquran: 


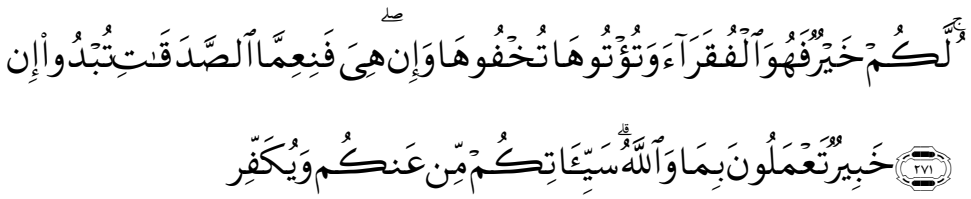

jika kamu Menampakkan sedekah(mu), Maka itu adalah baik sekali. dan jika kamu menyembunyikannya dan kamu berikan kepada orang-orang fakir, Maka Menyembunyikan itu lebih baik bagimu. dan Allah akan menghapuskan dari kamu sebagian kesalahan-kesalahanmu; dan Allah mengetahui apa yang kamu kerjakan. (QS. Al Baqoroh ayat 271)

\section{e. LingkunganHidup(Environment)}

Perusahaan tidak seharusnya terlibat dalam setiap jenis kegiatan yang mungkin menghancurkan atau merusak lingkungan. Dengan demikian, informasi yang terkait dengan penggunaan sumber daya dan program yang dilakukan untuk melindungi lingkungan harus diungkapkan (Othman, 2010:138) AlQuran dan Hadis mengutuk eksploitasi lingkungan:
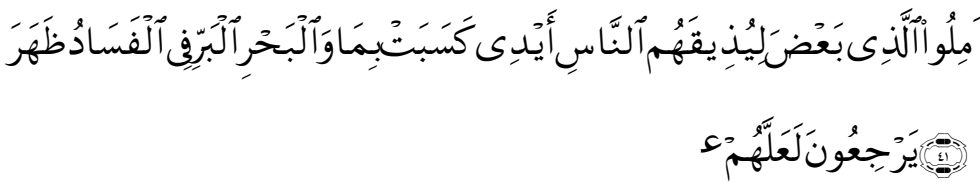

telah nampak kerusakan di darat dan di laut disebabkan karena perbuatan tangan manusia, supay Allah merasakan kepada mereka sebahagian dari (akibat) perbuatan mereka, agar mereka kembali (ke jalan yang benar). (QS Ar Ruum ayat 41).

\section{f. TataKelola Perusahaan(CorporateGovernance)}

Tata kelola perusahaan dalam ISR merupakan penambahan dari Othman et., al (2009) dimana tema ini tidak bisa dipisahkan dari perusahaan guna memastikan pengawasan pada aspek syariah perusahaan. Corporate governance merupakan suatu system hak,proses, dan kontrol secara keseluruhan yang 
ditetapkan secara internal dan eksternal atas manajemen sebuah entitas bisnis dengan tujuan untuk melindungi kepentingan - kepentingan stakeholder.

Prinsipnya dalam konsep corporate governance perusahaan harus mengungkapkan semua kegiatan yang dilarang seperti praktek monopoli, penimbunan barang yang diperlukan, manipulasi harga, perjudian, permainan dan segala jenis kegiatan yang melanggar hukum. Hal ini ditekankan dalam Alquran:

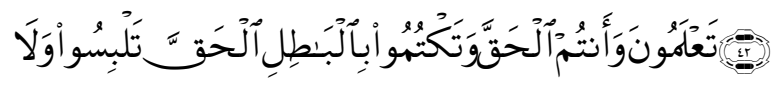

dan janganlah kamu campur adukkan yang hak dengan yang bathil dan janganlah kamu sembunyikan yang hak itu, sedang kamu mengetahui. (QS. Al Baqoroh ayat 42).

\section{Simpulan}

Konsep ISR didadasari atas filosofi Good Corporate Governance, dimana kepentingan stakeholder harus di akomodasi oleh korporasi melalui mekanisme pengendalian internal, manajemen resiko yang efektif dan pelaporan sosial yang berbasis syariah. ISR sebenarnya menjadi bagian strategi bisnis yang bertujuan untuk keberlanjutan perusahaan (profit sustainability), memberikan manfaat bagi masyarakat serta ikut dalam kepentingan sosial korporasi. Dimana tentu saja untuk mencapai semua itu harus mengedepankan nilai moral yang berperilaku etis yang dan dikemas dalam suat bentuk laporan annual report tentunya didasari oleh prinsip-prinsip syariah

ISR merupakan standar pelaporan kinerja social perusahaan - perusahaan yang berbasis syariah. Indeks dalam ISR dikembangkan dengan dasar dari standar pelaporan berdasarkan AAOIFI. Secara khusus indeks ini adalah perluasan. Dari standar pelaporan kinerja sosial yang meliputi harapan masyaraka tidak hanya mengenai peran perusahaan dalam perekonomian, tetapi juga peran 
perusahaan dalam perspektif spiritual. Selain itu indeks ini juga menekankan pada keadilan sosial terkait mengenai lingkungan, hak minoritas, dan karyawan. ISR tidak hanya membantu pengambilan keputusan bagi pihak muslim melainkan juga untuk membantu perusahaan dalam melakukan pemenuhan kewajiban terhadap Allah danmasyarakat menjadilandasan dasar atas terbentuknyaISR yang komprehensif. Kerangka syariah ini akan menghasilkan aspek-aspek material, moral, dan spiritual dalam pelaporan ISR perusahaan. Indeks ISR dalam kajian ini terdiri dari enam tema meliputi tema produk dan jasa, keuangan dan investasi, karyawan, sosial kemasyarakatn, lingkungan dan corporate governance. Dari beberapa indikator islamic social reporting dalam indeks yang digunakan sangat berusaha mengkaji pemahaman mengenai akuntabilitas, keadilan sosial dan kepemilikan sosial. Akuntabilitas sangat dipengaruhi oleh antara hubungan individu perusahaan dengan Allah. Hal ini berdasarkan tauhid, yang menegaskan bahwa segala sesuatu harus dipertanggungjawabkan kepada Allah SWT dan segala sesuatu yang dilakukan harus sesuai dengan perintah-Nya.Kemudian yang penting dalam ISR adalah konsep kepemilikan. Islam mengakui adanya kepemilikan individu, tetapi pada hakekatnya segala sesuatu adalah milik Allah SWT sehingga pemilik bertanggung jawab menggunakan sumber daya yang dimilikinya sesuai perintah Allah SWT dan bertujuan memberikan manfaat bagi umat. 


\section{Daftar Pustaka}

Abdullah, Wan Amalina Wan, Majella Percy dan Jenny Stewart, "Corporate Governance Disclosure Practices of Islamic banks: the Case of Islamic banks in the Southeast Asian and the Gulf Cooperation Council region", Journal of International Accounting Research (JIAR) Conference 2014.

Clark, Robert Charles, Corporate Law. New York: Aspen Law Publisher, 1986.

Daniri, Mas Achmad. Standarisasi Tanggung JawabSosial Perusahaan.Sambutan Menteri NegaraLingkungan Hidup pada Seminar Sehari "A Promise ofGold Rating: Sustainable CSR". Tanggal 23 Agustus2006.hlm.3. diambil dari www.menlh.go.id. Diaksespada tanggal 23Mei 2015

Fajar, Mukti. Tanggung Jawab Sosial Perusahaan di Indonesia, Yogyakarta: Pustaka Pelajar, 2013.

Farook, Sayd., "Social Responsibility for Islamic Financial Institutions: Laying Down A Framework". Journal of Islamic Economics, Banking and Finance, 2009.

Fitria , Soraya dan Dwi Hartanti, "Islam Dan Tanggung Jawab Sosial : Studi Perbandingan Pengungkapan Berdasarkan Global Reporting Initiative Indeks Dan Islamic Social Reporting Indeks". Simposium Nasional Akuntansi 13, Purwokerto, 2010.

Friedman, Milton "The Social Responsibility of Business is to Increase its Profits", The New York Times Magazine, 1 September 1970, http://www.colorado.edu/studenggroups/libertarians /issues/friedman-soc-resp-business.html. diunduh 23 April 2016.

Haniffa, R. "Social Reporting Disclosure-An Islamic Perspective", IndonesianManagement $\mathcal{E}$ Accounting Research 1(2),2002. 
Haniffa, R., \& Hudaib, M.. Exploring the Ethical Identity of Islamic Bank Via Communication in Annual Reporting. Journal of Business Ethic, 2007

Kartini, Dwi. Corporate Social Responsibility: Tranformasi Konsep Sustainablity Management dan Implementasi di Indonesia. Bandung: Refika Aditama, 2013.

Maali, Bassam, Casson, Peter, dan Napier, Christopher. 2006. "Social Reporting by Islamic Banks". ABACUS, Vol. 42. No. 2. The University of Sidney. Ausatralia.

Muhammad.. Manajemen Bank Syariah . Yogyakarta: UPP AMP YKPN. 2005

Othman , Rohana, A. Md. Thani, dan E.K. Ghani.. "Determinants of Islamic Social Reporting Among Top Shariah-Approved Companies in Bursa Malaysia", Research Journal of International Studies, Vol. 12, 2009.

Othman, Rohana\&A. M. Thani, "Islamic social reporting of listed companies in Malaysia". InternationalBusiness $\mathcal{E}$ Economics Research Journal, 9(4), 2010.

Ousama,A.A. and Fatima, A.H.,"The Determinants of Voluntary Disclosure in the Annual Reports by Shariah Approved Companies Listed on Bursa Malaysia" , Paper presented at IIUM International Accounting Conference 3, 26-28 June 2006, Kuala Lumpur, Malaysia

Richatul Jannah dan Dul Muid, "Analisis Faktor-Faktor Yang Mempengaruhi CarbonEmission Disclosure Pada Perusahaan Di Indonesia(Studi Empiris pada Perusahaan yang Terdaftar di Bursa Efek IndonesiaPeriode 2010-2012)". Diponegoro Journal Of Accounting Volume 3, Nomor 2, Tahun 2014.

Sayd Farouk, On Corporate Social Responsibility of Islamic Financial Institutions, Islamic Economic Studies, Vol. 15, No 1. July 2007, p. 
Siwar, C. dan M. T. Hossain "An analysis of Islamic CSR concept and th opinion of Malaysian managers". Management of Environmental Quality: An International Journal, 20,2009.

Sofyani, Hafiez, Islamic Social Reporting Perbankan Syariah Di Indonesia, Malaysia Dan Saudi Arabia: Sebuah Studi Menggunakan Anova, , Summary Research, Fakultas Ekonomika dan Bisnis, Universitas Gadjah Mada, Yogyakarta, 2014

Sofyani, Hafiez, I. Ulum, Daniel Syam dan Sri Wahyuni L., Islamic Social Reporting Index Sebagai Model Pengukuran Kinerja Sosial Perbankan Syariah (Studi Komparasi Indonesia Dan Malaysia), Jurnal Dinamika Akuntansi Vol. 4, No. 1, Maret 2012.

Sulaiman, Maliah bt. dan Roger Willett, Using the HofstedeGray framework to argue normatively for an extension of Islamic Corporate Reports. Malaysian Accounting Review. Vol 2 (1),2003.

Wolfe, Alan. "The Modern Corporation: Private Agent or Public Actor?", Washington and Lee Law Review 50 (Fall), 1993. 